Original Article

\title{
Enhancement of Annexin $\mathrm{V}$ in response to combination of epigallocatechin gallate and quercetin as a potent arrest the cell cycle of colorectal cancer
}

\author{
Aumento da anexina $\mathrm{V}$ em resposta à combinação de galato de epigalocatequina $\mathrm{e}$ \\ quercetina como uma potente parada do ciclo celular do câncer colorretal
}

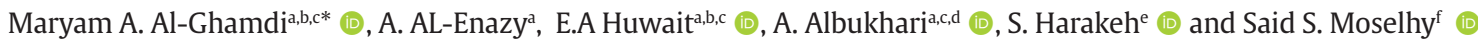 \\ ${ }^{a}$ King Abdulaziz University, Faculty of Science, Department of Biochemistry, Jeddah, Saudi Arabia

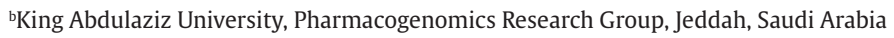 \\ 'King Abdulaziz University, King Fahad Medical Research Center, Experimental Biochemistry Unit, Jeddah, Saudi Arabia \\ ${ }^{d}$ King Abdulaziz University, King Fahad Medical Research Center, Cancer and Mutagenesis Unit, Jeddah, Saudi Arabia \\ ${ }^{e}$ King Abdulaziz University - KAU, King Fahd Medical Research Center - KFMRC, Special Infectious Agents Unit, Jeddah, Kingdom of Saudi \\ Arabia (KSA) \\ ${ }_{\mathrm{f} A i n}$ Shams University, Faculty of Science, Department of Biochemistry, Cairo, Egypt.
}

\begin{abstract}
Colorectal cancer (CRC) is one of the most common cancers leading to comorbidities and mortalities globally. The rational of current study was to evaluate the combined epigallocatechin gallate and quercetin as a potent antitumor agent as commentary agent for therapeutic protocol. The present study investigated the effect of epigallocatechin Gallate (EGCG) (150mg) and quercetin (200mg) at different proportions on proliferation and induction of apoptosis in human colon cancer cells (HCT-116). Cell growth, colonogenic, Annexin V in addition cell cycle were detected in response to phytomolecules. Data obtained showed that, the colony formation was inhibited significantly in CRC starting from the lowest concentration tested of $10 \mu \mathrm{g} / \mathrm{mL}$ resulting in no colonies as visualized by a phase-contrast microscope. Data showed a significant elevation in the annexin $\mathrm{V}$ at $100 \mu \mathrm{g} / \mathrm{mL}$ EGCG(25.85\%) and $150 \mu \mathrm{g} / \mathrm{mL}$ quercetin (48.35\%). Moreover, cell cycle analysis showed that this combination caused cell cycle arrest at the $\mathrm{G}_{1}$ phase at concentration of $100 \mu \mathrm{g} / \mathrm{mL}$ (72.7\%) and $150 \mu \mathrm{g} / \mathrm{mL}$ (75.25\%). The combined effect of epigallocatechin Gallate and quercetin exert antiproliferative activity against CRC, it is promising in alternative conventional chemotherapeutic agent.
\end{abstract}

Keywords: colorectal cancer, epigallocatechin gallate, quercetin, apoptosis.

\begin{abstract}
Resumo
O câncer colorretal (CCR) é um dos cânceres mais comuns, levando a comorbidades e mortalidade em todo o mundo. O racional do presente estudo foi avaliar a combinação de galato de epigalocatequina e quercetina como um agente antitumoral potente como agente de comentário para protocolo terapêutico. O presente estudo investigou o efeito de galato de epigalocatequina (EGCG) $(150 \mathrm{mg})$ e quercetina $(200 \mathrm{mg})$ em diferentes proporções na proliferação e indução de apoptose em células de câncer de cólon humano (HCT-116). O crescimento celular, colonogênico, anexina $\mathrm{V}$, além do ciclo celular foram detectados em resposta a fitomoléculas. Os dados obtidos mostraram que a formação de colônias foi inibida significativamente no CRC a partir da concentração mais baixa testada de $10 \mu \mathrm{g} / \mathrm{mL}$, resultando em nenhuma colônia conforme visualizado por um microscópio de contraste de fase. Os dados mostraram uma elevação significativa na anexina V a $100 \mu \mathrm{g} / \mathrm{mL}$ de EGCG $(25,85 \%)$ e $150 \mu \mathrm{g} / \mathrm{mL}$ de quercetina (48,35\%). Além disso, a análise do ciclo celular mostrou que essa combinação causou parada do ciclo celular na fase G1 na concentração de $100 \mu \mathrm{g} / \mathrm{mL}$ (72,7\%) e $150 \mu \mathrm{g} / \mathrm{mL}$ (75,25\%). O efeito combinado da epigalocatequina galato e quercetina exerce atividade antiproliferativa contra o CCR, é promissor como agente quimioterápico alternativo convencional.
\end{abstract}

Palavras-chave: câncer colorretal, galato de epigalocatequina, quercetina, apoptose.

*e-mail: maaalghamdi3@kau.edu.sa

Received: February 14, 2021 - Accepted: March 30, 2021 


\section{Introduction}

Colorectal cancer (CRC) is one of the five top most common types of cancers in the world that affects both men and women. In 2018, it was estimated that around 1.1 million new cases of colon cancer were diagnosed with an estimation of 500,000 colon cancer-related deaths worldwide (Bray et al., 2018). More than half of the cases (60\%) have been reported in developed countries. CRC adenocarcinoma is formed either in the tissues of the colon, the mucosal colonic polyps, or the rectum (Cappell, 2005). It is believed that the development of CRC is influenced by both genetic (inherited) and environmental (lifestyle) factors (Amersi et al., 2005). CRC could occur in patients at all ages, but the risk increases with age gradually. Patient's survival is directly linked to the metastasis of primary colorectal tumors and accounts for $90 \%$ of patients' mortality. Nearly half of the subjects with CRC can be cured by surgery and multimodal treatment. However, therapeutic options are restricted especially for metastasized patients. This is demonstrated by 5-year-survival rates, which are higher (90\%) for the early stage patients followed by $65 \%$ for patients with regional lymph node metastasis, and it is quite lower (10\%) in patients with advanced metastatic disease (Koelzer et al., 2015).

Fluorouracil chemotherapy has been the only approved treatment for the management of metastatic colorectal cancer (mCRC) since 1950s (Petrelli et al., 1989). Subsequently, oxaliplatin, irinotecan, and leucovorin along with fluorouracil-based chemotherapeutical agents have been proven to be well-tolerated with increased response rate, time of progression and survival in patients with $\mathrm{MCRC}$, and are used as a reference first-line therapy against mCRC (Zhang et al., 2015). During the last decade, novel targeted therapies, as a single agent or combinations, have been used for the treatment of mCRC. Bevacizumab (Avastin) is the most common one that has been used to treat mCRC patients (Zhang et al., 2015). However, there is an urgent need to develop alternative or complementary treatment regimens to counteract the resistance to chemotherapy, concentration-limiting toxicities, off-target effects and relapse.

Previous reports stated that, the use of natural products in the treatment of CRC has attracted a lot of interest (Katz and Baltz, 2016; Siddiqui et al., 2014). The protective effect of natural compounds may be attributed to the presence of numerous phytochemicals such as resveratrol, quercetin, rutin, catechin, myricetin, kaempferol, and Epigallocatechin gallate (EGCG). EGCG has been reported to modulate multiple key elements in signal transduction pathways affecting cellular proliferation, differentiation, apoptosis, inflammation, angiogenesis and metastasis in CRC (Araujo et al., 2011; Kuerban et al., 2017; Soengas Fernández et al., 2011; Moselhy et al., 2018). Initial studies have revealed that these compounds are able to affect cell proliferation, cell cycle regulation, and usually participate in multiple signaling pathways which are often disrupted in tumor initiation, proliferation and propagation (Kotecha et al., 2016). Generally, phytochemicals do not interfere with chemotherapy; instead, they enhance the effects of the widely used chemotherapeutic agent in a concentration-dependent manner (Iqbal et al., 2017; Simone II et al., 2007).

Many previous studies have reported the use of a combination of, two or often more, phytochemicals to evaluate their anti-carcinogenic potential, both in vitro and in vivo settings against different human cancer cell lines as well as in laboratory animals (Araújo et al., 2011; Fantini et al., 2015; Ramos 2008; Scalbert et al., 2005). The aim of the current study was to investigate the effect of phytobiological (PB) on proliferation and induction of apoptosis against HCT116 human colon cancer cells. The chemical composition of the PB contained. Previous studies have shown the anti-proliferative and anti-cancerous potential of PB in breast, sarcoma, skin and head and neck cancer cell lines (Alqarni et al., 2017; Niedzwiecki et al., 2016; Roomi et al., 2011, 2015).

Many previous studies have reported the antiproliferative and anticancer effect of some polyphenols against colon cancer using in vitro models (Araujo et al., 2011; Fantini et al., 2015; Ramos, 2008; Scalbert et al., 2005). However, the in vitro studies with a mixture of all these polyphenols are quite limited and the mechanism of action is still unclear. Therefore, building upon the previous studies, we evaluated the effect of different concentrations of combined effect of quercetin and EGCG on HCT116 CRC cells line. To the best of our knowledge, it is the first time that $\mathrm{PB}$ was used to evaluate its in vitro anticancer effect on CRC cells. The effect of individual phytochemical was previously studied, for that the rational of this study investigated the combined effect EGCG and quercetin in cell cycle arrest CRC cell lines as a target for antitumor action.

\section{Materials and Methods}

\subsection{Preparation of stock solution}

The EGCG and quercetin (Santa Clara, California, USA) used in this study was a generous gift from Dr. Steve Harakeh. The Stock solutions of the EGCG and quercetin were prepared with a concentration of $100 \mathrm{mg} / \mathrm{mL}$ in pure DMSO (Thermo Fisher, USA) and were stored in aliquots at $-20{ }^{\circ} \mathrm{C}$. Routine working standard solutions were prepared with diluting $100 \mathrm{ul}$ of stock solution in 9,900 $\mu$ L FBS-free DMEM. Different concentrations of the drug were prepared and used for all the experiments (10, $25,50,75,100,150 \mu \mathrm{g} / \mathrm{mL})$. For each experiment, fresh dilution of the drug was used in the treatment and for all the experiments where DMSO was used as a solvent, the final concentration of DMSO was maintained at 0.1-0.5\%. The doses given according to previous study.

\subsection{Cell culture}

The human colorectal carcinoma from a cell line (HCT-116) was obtained from the American Type Culture Collection (ATCC, Manassas, VA, USA) and maintained in a humidified incubator with $5 \% \mathrm{CO}_{2}$ at $37^{\circ} \mathrm{C}$. The cells were grown in Dulbecco's Modified Eagle's Medium (DMEM) (UFC Biotech, KSA) supplemented with 10\% FBS (Gibco, USA) and 1\% penicillin-streptomycin (UFC Biotech, KSA) antibiotics (100 units/mL). 


\subsection{Cell growth assay}

The cell growth effect of the EGCG and quercetin on CRC cells was evaluated through a rapid colorimetric cell proliferation assay using WST-1 reagent (Abcam, USA). The cells were seeded in a 96-well plate at a density of $8 \times 10^{3}$ cells/well in $100 \mathrm{uL}$ of culture medium and incubated for 24 hours. The cells were treated with different concentrations of EGCG and quercetin at different concentrations and incubated for 24,48 and $72 \mathrm{~h}$. After incubation for different time periods, WST-1 solution $(10 \mu \mathrm{L})$ was added to each well and incubated for $2 \mathrm{~h}$ at $37^{\circ} \mathrm{C}$. Finally, the absorbance was recorded at $450 \mathrm{~nm}$ with an ELx800 ${ }^{\mathrm{TM}}$ microplate ELISA reader (Biotek, USA) and the results were analyzed by the Gen5 software (Biotek, USA). The percentage of cell growth was calculated relatively to the control (untreated).

\subsection{Clonogenic assay}

The cells were seeded in a 6-well plate at a density of 1000 cells/well in $3 \mathrm{~mL}$ of culture medium and incubated for $24 \mathrm{~h}$. The culture medium was changed and the cells were treated with different concentrations of EGCG and quercetin. The cells were incubated at $37{ }^{\circ} \mathrm{C}$ in a $\mathrm{CO}_{2}$ incubator for colony formation for 10 days. The media was gently removed from each well by aspiration and washed with $2 \mathrm{~mL}$ DPBS. Then, colonies were fixed with $1.5 \mathrm{~mL}$ of $4 \%$ formaldehyde for 30 minutes, washed with $2 \mathrm{~mL}$ of DPBS and then $1 \mathrm{~mL}$ of $0.5 \%$ of crystal violet was added and incubated for 30 mins. Then the stain was removed by washing with $2 \mathrm{~mL}$ DPBS and the plates were allowed to dry. The wells with colonies with $>50$ cells were counted under a phase-contrast microscope.

\subsection{Annexin V/PI assay}

The APC Annexin V kit (BD Bioscience, USA) was used for apoptotic assay according to the manufacturer's recommendations. In brief, the cells were seeded in 6-well plate at a density of $3 \times 10^{5}$ cells/well in $2 \mathrm{~mL}$ of culture medium and incubated for $24 \mathrm{~h}$. The culture medium was changed, and cells were treated with different concentrations of EGCG and quercetin $(10,25,50,100$, $150 \mu \mathrm{g} / \mathrm{mL})$. Cells were trypsinized with (0.05\%) trypsinEDTA $(500 \mu \mathrm{L})$ and incubated for $7 \mathrm{~min}$ and then $2 \mathrm{~mL}$ of culture medium was added and centrifuged at $1200 \mathrm{rpm}$ for $5 \mathrm{~min}$. The supernatant was discarded, and the pellet was resuspended twice in ice-cold PBS and then the cells were resuspended in FACS tubes $\left(1 \times 10^{5}\right.$ cells $)$ in $100 \mu \mathrm{L} 1 \mathrm{x}$ binding buffer. APC Annexin V $(3 \mu \mathrm{L})$ and PI $(5 \mu \mathrm{L})$ were added, gently vortexed and incubated for $15 \mathrm{~min}$ at room temperature in the dark. Finally, $300 \mu \mathrm{L}$ of $1 \mathrm{x}$ Binding Buffer was added to each tube and analyzed by flow cytometer (BD Biosciences, USA).

\subsection{Cell cycle analysis}

The cell cycle analysis was done using a commercially available BD Cycletest ${ }^{\mathrm{TM}}$ Plus DNA kit (BD Bioscience, USA) as per the manufacturer's protocol. The cells were seeded in 6-well plate at a density of $3 \times 10^{5}$ cells/well in $2 \mathrm{~mL}$ of culture medium and incubated for $24 \mathrm{~h}$. The culture medium was changed, and cells were treated with different concentrations of EGCG and quercetin (10, 25, $50,100,150 \mu \mathrm{g} / \mathrm{mL})$. Cells were trypsinized with $(0.05 \%)$ trypsin-EDTA $(500 \mu \mathrm{L})$, incubated for $7 \mathrm{~min}$ and then $2 \mathrm{~mL}$ of culture medium was added and centrifuged at $1200 \mathrm{rpm}$ for $5 \mathrm{~min}$. The supernatant was discarded, pellet was resuspended twice in ice-cold PBS and then into the FACS tubes. The staining procedure for DNA ploidy analysis requires a test sample of $5 \times 10^{5}$ cells. The reagents were added as per the manufacturer's instructions and finally, the tubes were incubated for $10 \mathrm{~min}$ in the dark. The samples were then analyzed on the flow cytometer.

\subsection{Statistical analysis}

Statistical analyses (student t test or two-way ANOVA) was performed using GraphPad Prism 6 software (GraphPad, San Diego, USA). Results are presented as Mean \pm SEM of triplicates in the same experiment or three independent experiments. The significant statistical differences have been designated as ${ }^{*} p<0.05,{ }^{* *} p<0.01$ and ${ }^{* * *} p<0.001$.

\section{Results}

EGCG and quercetin treatment inhibits the cell growth of HCT116 cells in a concentration-dependent manner

Initially, we evaluated the antiproliferative effect of EGCG and quercetin on HCT116 cells using WST-1 staining (Figure 1). Treatment of HCT116 cells for $24 \mathrm{~h}$ with EGCG and quercetin exerted a significant decrease in the cell growth in a concentration-dependent manner. At $10 \mu \mathrm{g} / \mathrm{mL}$, there was a significant decrease in the cell growth to $68 \%$ compared to the control untreated cells. Similarly, a significant decrease was observed to $69 \%, 69 \%, 53 \%$, and $48 \%$ at different concentrations $(25,50,100$ and $150 \mu \mathrm{g} / \mathrm{mL}$, respectively) (Figure 1A). Moreover, it was observed that after $48 \mathrm{~h}$ treatment, the percentage of viable cells at 10 , $25,50,100$ and $150 \mathrm{ug} / \mathrm{mL}$ was $74 \%, 69 \%, 72 \% 66 \%$ and $58 \%$, respectively, compared to untreated control cells (Figure 1B). Furthermore, when we treated the cells for $72 \mathrm{~h}$ the cell viabilities at 10, 25, 50, 100 and $150 \mu \mathrm{g} / \mathrm{mL}$ were $96 \%, 88 \%, 86 \%, 71 \%$ and $64 \%$, respectively (Figure $1 \mathrm{C}$ ). The IC50 values of EGCG and quercetin at 24, 48 and $72 \mathrm{~h}$ were calculated as $145 \pm 3,167 \pm 1,248 \pm 1.7 \mu \mathrm{g} / \mathrm{mL}$, respectively.

EGCG and quercetin suppresses the formation of colonies in HCT116 cells

To further verify the inhibitory effect of PB against HCT116 cells, the colony formation assay was performed using different concentrations of EGCG and quercetin (25, 50,100 and $150 \mu \mathrm{g} / \mathrm{mL}$ ). As shown in Figure 2, EGCG and quercetin exerted a concentration-dependent inhibitory effect on the colony formation of HCT116 cells. EGCG and quercetin at a concentration of $10 \mathrm{ug} / \mathrm{mL}$ significantly decreased the number of colonies of HCT116 cells by $46.92 \%$ compared to the control cells. However, at concentrations of 25 and $50 \mathrm{ug} / \mathrm{mL}$, there were individual cells present in the medium, but colony formation was not observed even after 7 days. Interestingly, at higher concentrations of 100 and $150 \mathrm{ug} / \mathrm{mL}$, neither cells nor colonies were visualized. 
A)

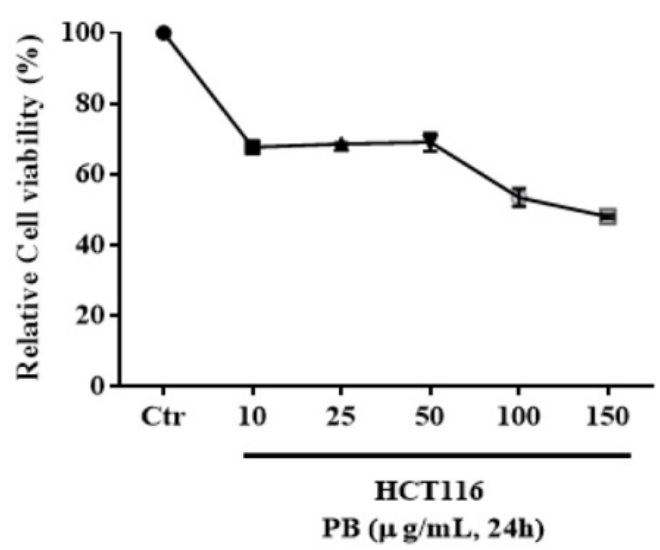

C)

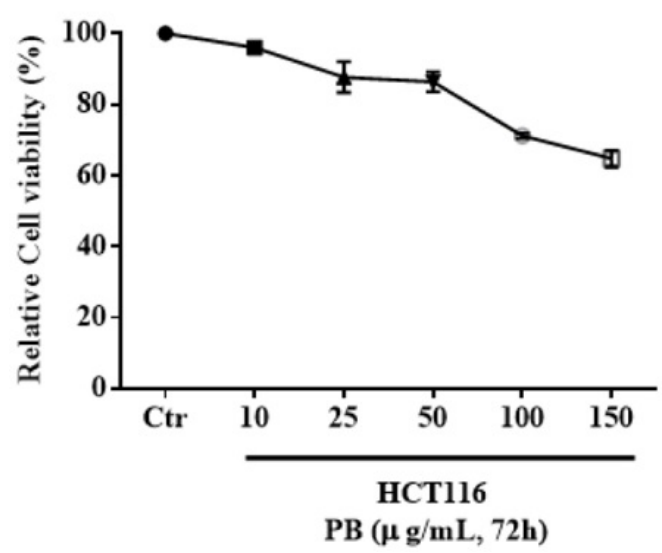

B)

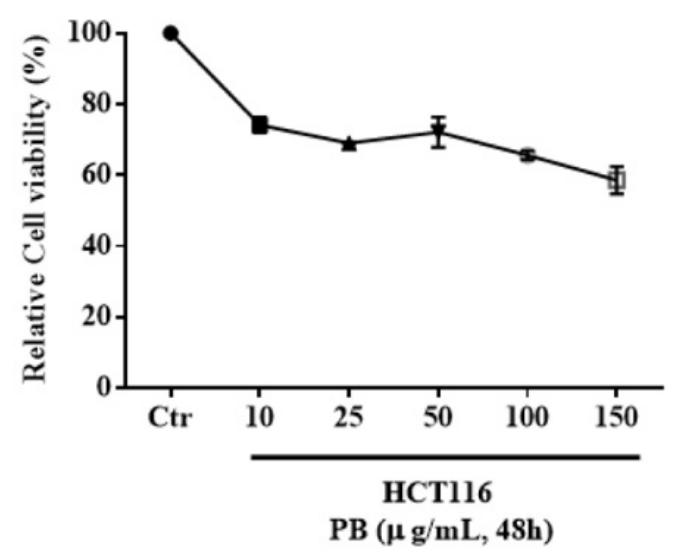

Figure 1. Effect of Phytobiological mixture (PB) on HCT116 cell growth. To evaluate the antiproliferative effect of PB, HCT116 Cells were exposed to increasing concentrations of PB for $24 \mathrm{~h}(\mathrm{~A}), 48 \mathrm{~h}$ (B) and $72 \mathrm{~h}$ (C). Cell growth rate was assessed by WST-1 assay as indicated in the methods and materials. The data are representative of three different experiments. Values are shown as mean \pm S.E.M. $(n=5)$ versus respective control.

\section{EGCG and quercetin exerts a pro-apoptotic effect on HCT116 cells}

To study the hypothesis that EGCG and quercetin could have the potential to induce apoptosis in HCT116 cells, we performed a concentration-dependent Annexin V and PI double staining to detect the apoptosis stages. The cells were treated with EGCG and quercetin at different concentrations $(25,50,100$ and $150 \mu \mathrm{g} / \mathrm{mL})$ for $24 \mathrm{~h}$. As shown in Figure 3 , the percentage of annexin $\mathrm{V}$ positive cells significantly increased from a concentration of $50 \mathrm{ug} / \mathrm{mL}(6.15 \%)$ to $100 \mu \mathrm{g} / \mathrm{mL}$ (25.85\%) compared to untreated cells. At the highest concentration of $150 \mu \mathrm{g} / \mathrm{mL}$, the percentage of annexin $V$ positive cells stood at $48.35 \%$. This could suggest that the pro-apoptotic effect could have been initiated in the cells at this stage as a result of the compromised plasma membrane and subsequent exposure of phosphatidylserine which needs to be investigated further.

EGCG and quercetin treatment induces G1 arrest in HCT116 cells
To explore the effect of EGCG and quercetin on cell cycle progression of HCT116 cells, the cells were exposed to the indicated concentrations of PB for $24 \mathrm{~h}$. As shown in Figure 4, EGCG and quercetin -treatment induced a significant G1 phase arrest as compared to the control untreated cells. As shown in Figure 4, the percentage of cells in G1 phase were 71, 70.06, 72.7, 81.7\%; in 'S' phase were 19.1, 26.2, 25.8, 17.2\% and finally in 'G2' phase the percentage of cells were 9.83, 11.4, 3.7, 1.9\%; in control, 50,100 and $150 \mu \mathrm{g} / \mathrm{mL}$, respectively.

\section{Discussion}

Globally, colon cancer is one of the most common cancers affecting men and women with a significant number of annual mortalities. The chemotherapeutic regimens used against this cancer acquire resistance over a prolonged period in addition to exerting off-target toxicities (Cappell, 2005; Koelzer et al., 2015; Zhang et al., 2015). 


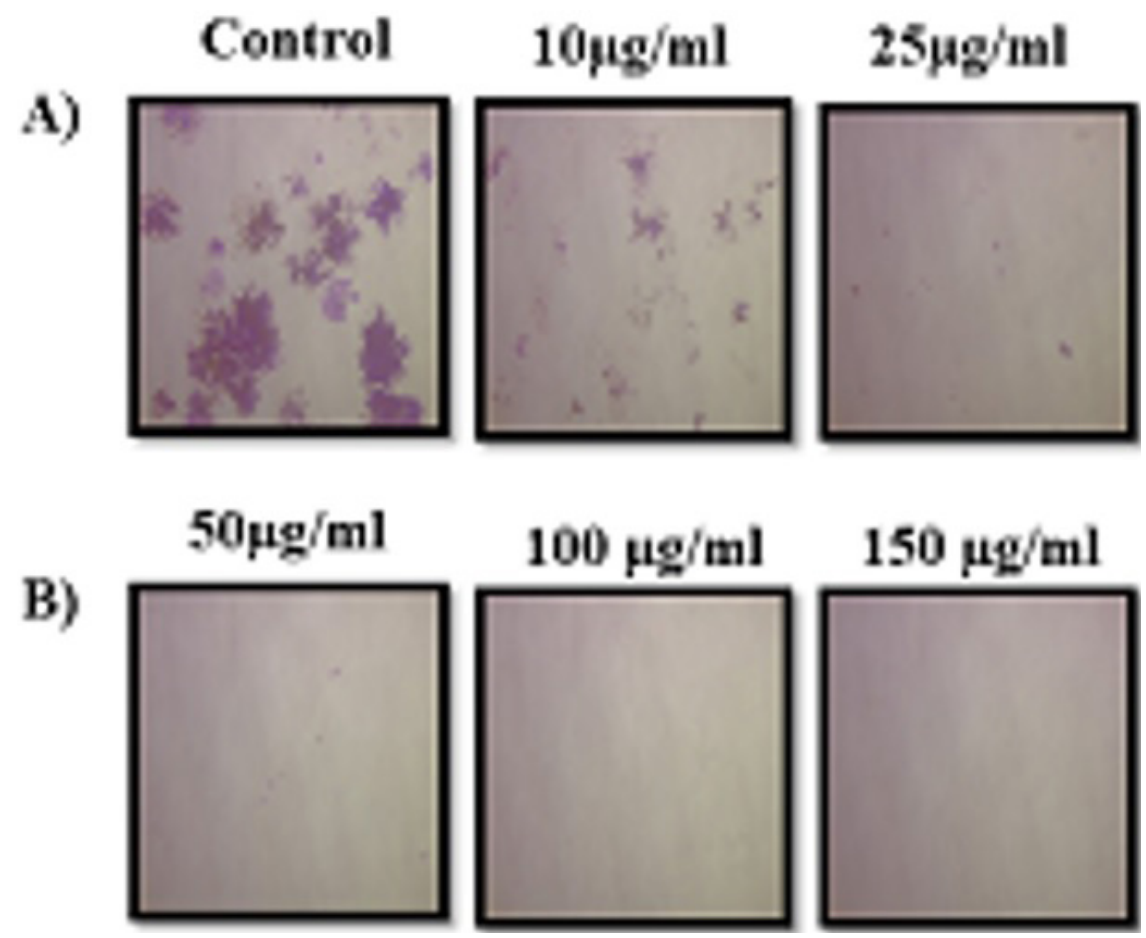

Figure 2. Clonogenic assays in colon cancer cells treated with Phytobiological mixture. Colon cancer, HCT116 were plated at very low density in six-well plates and incubated $24 \mathrm{~h}$ at $37^{\circ} \mathrm{C}$. Cells were left untreated ; Control or treated by addition of 10, 25, (Row A), 50, 100 and $150 \mu \mathrm{g} / \mathrm{mL}$ (Row B). After 10 days of treatment, cells were washed with cold PBS, fixed with paraformaldehyde, and stained with crystal violet solution.

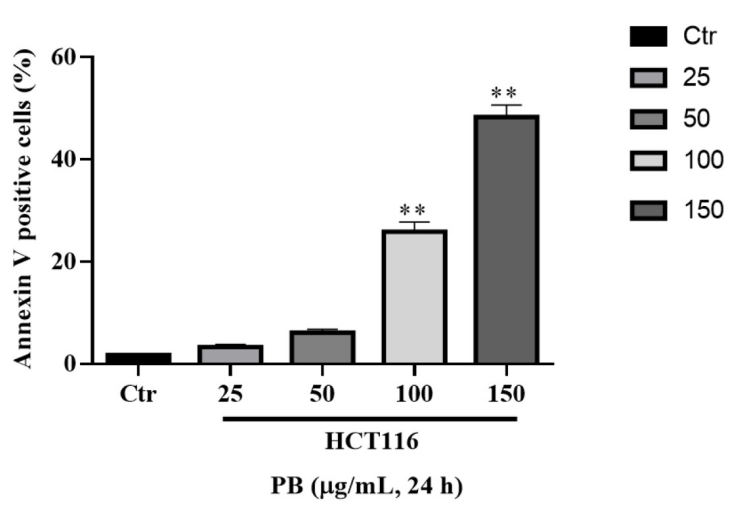

Figure 3. Effect of Phytobiological mixture (PB) on apoptosis in HCT116 cells. To evaluate the apoptotic effect of PB, cells were exposed to increasing concentrations of PB for $24 \mathrm{~h}$. Apoptosis in HCT116 cells was assessed by flow cytometry using the Annexin V/7AAD staining apoptosis assay. Annexin V level was significantly increased as means \pm S.E.M. $(\mathrm{n}=5) ;{ }^{* *} p<0.01$, versus respective control.

Therefore, there is a persistent need to explore alternative therapeutic strategies to prolong the patient survival and reduce toxicities. In recent years, many medicinal plants have attracted the attention of researchers globally due to their substantial sources of substances with active antiproliferative and anticarcinogenic potential (Kaur et al., 2018). Natural product research has gained momentum in

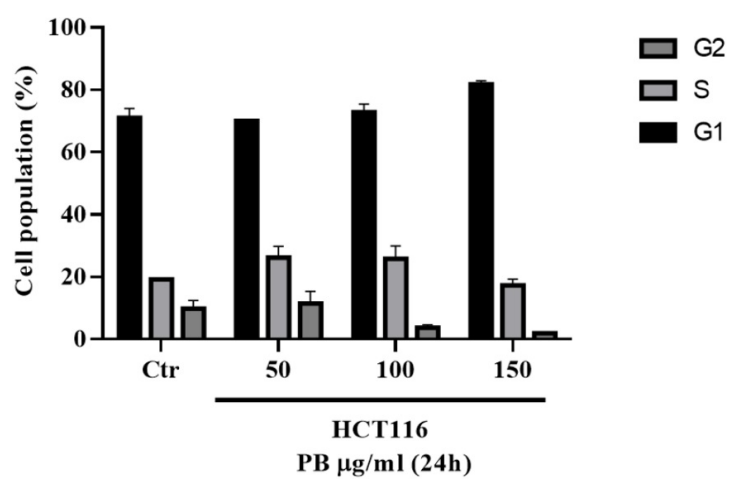

Figure 4. Effects of Phytobiological mixture (PB) on the cell cycle progression of colon cancer cells, HCT116. Cells were seeded in 6-well plate and then treated with PB at increasing concentrations for $24 \mathrm{~h}$. It was observed that there was a significant G1 phase cell cycle arrest with the successive increase in the concentration. The data are representative of three different experiments. Values are shown as mean \pm S.E.M. $(\mathrm{n}=5) ;{ }^{*} p<0.05 ;{ }^{* *} p<0.01$ versus respective control.

the circles of drug discovery leading to the novel anticancer drugs today (Rajesh et al., 2015).

We noticed that there was a significant decrease in the percentage of viable cells at 24,48 and $72 \mathrm{~h}$ in a concentration-dependent manner. However, the inhibitory effect of PB was more pronounced at $24 \mathrm{~h}$ than 48 or $72 \mathrm{~h}$, which could be further tested with time-dependent 
assays. A previous study has shown that PB-treatment for $72 \mathrm{~h}$ demonstrated a concentration-dependent toxicity to HCT116 cells in vitro with $27 \%(p=0.0003)$ at $75 \mathrm{ug} / \mathrm{mL}$ and $48 \%(p=0.0004)$ at $100 \mathrm{ug} / \mathrm{mL}$, compared to the control (Roomi et al., 2015). Subsequently, we further verified the inhibitory effect of PB against HCT116 CRC cells proliferation using colony formation assay which revealed a significant inhibition of colony formation of PB-treated HCT116 CRC cells.

Apoptosis induction is a classical approach in initiating cell death characterized by biochemical and morphological hallmarks (Kumaraswamy et al., 2013; Kitazumi and Tsukahara, 2011). The annexin V/PI assay with flow cytometry showed that PB induced the pro-apoptotic effect in HCT116 cells in a concentration dependent manner at $24 \mathrm{~h}$. At the highest concentration of $150 \mathrm{ug} / \mathrm{mL}$, the percentage of annexin $\mathrm{V}$ positive cells stood at $28.55 \%$. Our findings are in accordance with the previous studies that reported that the exposure of MDA-MB-231 breast cancer cells to $\mathrm{PB}$ resulted in the induction of apoptosis in a concentration-dependent manner (Alqarni et al., 2017).

Progression through the cell cycle is regulated carefully to avoid proliferation or mitosis when adverse conditions exist. DNA damage causes cell cycle arrest in G1, S or G2 to prevent replication of damaged DNA or to prevent aberrant mitosis (Srivastava and Singh, 2004). Dysregulation of the cell cycle is a key feature of tumour cells and therefore targeting the cell cycle of cancer cells is an important approach in cancer therapy (Goi et al., 1997). In the present study, PB induced G1 phase cell cycle arrest in HCT116 CRC cells at high concentrations of 100 and $150 \mathrm{ug} / \mathrm{mL}$. It can be inferred that at higher concentrations, PB may have arrested the replication of DNA and hence prevented the cells to enter into the $\mathrm{G} 2$ phase leading to the decreased cell division and overall inhibitory effect on the cancer cell growth. Previous studies have also reported that exposure of MDA-MB-231 to concentrations of PB of $10 \mathrm{ug} / \mathrm{mL}$ and $30 \mathrm{ug} / \mathrm{mL}$ resulted in a significant cell cycle arrest at the G1/S phase with a population of $25.3 \pm 1.6 \%$ and $20.5 \pm 0.4 \%$, respectively, as compared to the control untreated cells $12.4 \pm 1.5 \%$ ( $p<0.001$ ) (Alqarni et al., 2017). However, further molecular studies at the protein and gene level are necessary which can enable us to arrive at a concrete decision. As we mentioned earlier that the combination of bioactive polyphenols in the treatment regimen could increase the bioavailability of the bioactive component and could be a good supportive agent for the current treatments without any detrimental effects.

\section{Conclusion}

The present study showed that the EGCG combined with quercetin has a potential to exert pro-apoptotic inhibitory effect accompanied by cell cycle arrest in HCT116 CRC cells. It is promising approach to identify a complementary treatment regimen for colon cancer. However, further in vivo evaluation and molecular investigations are recommended.

\section{Acknowledgements}

This project was funded by the Deanship of Scientific Research (DSR), at King Abdulaziz University, Jeddah, under grant no. (D-694-247-1437). The authors, therefore, gratefully acknowledge with thanks the technical and financial support at DSR.

\section{References}

ALQARNI, A., ALAMOUDI, A., AJABNOOR, G., AL-ABD, A., NIEDWIECKI, A., RATH, M. and HARAKEH, S., 2017. Inhibition of proliferation and induction of apoptosis by a novel phytobiological mixture against breast cancer cell lines. Cancer Research, vol. 77, no. 13, suppl., pp. 4208.

AMERSI, F., AGUSTIN, M. and KO, C.Y., 2005. Colorectal cancer: epidemiology, risk factors, and health services. Clinics in Colon and Rectal Surgery, vol. 18, no. 3, pp. 133-140. http://dx.doi. org/10.1055/s-2005-916274. PMid:20011296.

ARAÚJO, J.R., GONÇALVES, P. and MARTEL, F., 2011. Chemopreventive effect of dietary polyphenols in colorectal cancer cell lines. Nutrition Research, vol. 31, no. 2, pp. 77-87. http://dx.doi. org/10.1016/j.nutres.2011.01.006. PMid:21419311.

BRAY, F., FERLAY, J., SOERJOMATARAM, I., SIEGEL, R.L., TORRE, L.A. and JEMAL, A., 2018. Global cancer statistics 2018: GLOBOCAN estimates of incidence and mortality worldwide for 36 cancers in 185 countries. CA: a Cancer Journal for Clinicians, vol. 68, no. 6, pp. 394-424. http://dx.doi.org/10.3322/caac.21492. PMid:30207593.

CAPPELL, M.S., 2005. The pathophysiology, clinical presentation, and diagnosis of colon cancer and adenomatous polyps. The Medical Clinics of North America, vol. 89, no. 1, pp. 1-42, vii. http://dx.doi.org/10.1016/j.mcna.2004.08.011. PMid:15527807.

FANTINI, M., BENVENUTO, M., MASUELLI, L., FRAJESE, G., TRESOLDI, I., MODESTI, A. and BEI, R., 2015. In vitro and in vivo antitumoral effects of combinations of polyphenols, or polyphenols and anticancer drugs: perspectives on cancer treatment. International Journal of Molecular Sciences, vol. 16, no. 12, pp. 9236-9282. http://dx.doi.org/10.3390/ijms16059236. PMid:25918934.

GOI, K., TAKAGI, M., IWATA, S., DELIA, D., ASADA, M., DONGHI, R., TSUNEMATSU, Y., NAKAZAWA, S., YAMAMOTO, H., YOKOTA, J., TAMURA, K., SAEKI, Y., UTSUNOMIYA, J., TAKAHASHI, T., UEDA, R., ISHIOKA, C., EGUCHI, M., KAMATA, N. and MIZUTANI, S., 1997. DNA damage-associated dysregulation of the cell cycle and apoptosis control in cells with germ-line p53 mutation. Cancer Research, vol. 57, no. 10, pp. LP-1902.

IQBAL, J., ABBASI, B.A., MAHMOOD, T., KANWAL, S., ALI, B., SHAH, S.A. and KHALIL, A.T., 2017. Plant-derived anticancer agents: a green anticancer approach. Asian Pacific Journal of Tropical Biomedicine, vol. 7, no. 12, pp. 1129-1150. http://dx.doi. org/10.1016/j.apjtb.2017.10.016.

KATZ, L. and BALTZ, R.H., 2016. Natural product discovery: past, present, and future. Journal of Industrial Microbiology E' Biotechnology, vol. 43, no. 2-3, pp. 155-176. http://dx.doi. org/10.1007/s10295-015-1723-5. PMid:26739136.

KAUR, V., KUMAR, M., KUMAR, A., KAUR, K., DHILLON, V.S. and KAUR, S., 2018. Pharmacotherapeutic potential of phytochemicals: implications in cancer chemoprevention and future perspectives. Biomedicine and Pharmacotherapy, vol. 97, pp. 564-586. http:// dx.doi.org/10.1016/j.biopha.2017.10.124. PMid:29101800.

KITAZUMI, I. and TSUKAHARA, M., 2011. Regulation of DNA fragmentation: the role of caspases and phosphorylation. 
The FEBS Journal, vol. 278, no. 3, pp. 427-441. http://dx.doi. org/10.1111/j.1742-4658.2010.07975.x. PMid:21182594.

KOELZER, V.H., HERRMANN, P., ZLOBEC, I., KARAMITOPOULOU, E., LUGLI, A. and STEIN, U., 2015. Heterogeneity analysis of Metastasis Associated in Colon Cancer 1 (MACC1) for survival prognosis of colorectal cancer patients: a retrospective cohort study. BMC Cancer, vol. 15, no. 1, pp. 160. http://dx.doi. org/10.1186/s12885-015-1150-z. PMid:25884643.

KOTECHA, R., TAKAMI, A. and ESPINOZA, J.L., 2016. Dietary phytochemicals and cancer chemoprevention: a review of the clinical evidence. Oncotarget, vol. 7, no. 32, pp. 52517-52529. http://dx.doi.org/10.18632/oncotarget.9593. PMid:27232756.

KUERBAN, A., YAGHMOOR, S.S., ALMULAIKY, Y.Q., MOHAMED, Y.A., RAZVI, S.S.I., HASAN, M.N., MOSELHY, S.S., AL-GHAFARI, A.B., ALSUFIANI, H.M., KUMOSANI, T.A. and AL-MALKI, A., 2017. Therapeutic effects of phytochemicals of brassicaceae for management of obesity. Journal of Pharmaceutical Research International, vol. 19, no. 4, pp. 1-11. http://dx.doi.org/10.9734/ JPRI/2017/37617.

KUMARASWAMY, K.L., ARCHANA, M., BASTIAN. and YOGESH, T.L., 2013. Various methods available for detection of apoptotic cells: a review. Indian Journal of Cancer, vol. 50, no. 3, pp. 274-283. http://dx.doi.org/10.4103/0019-509X.118720. PMid:24061471.

MOSELHY, S.S., RAZVI, S., HASAN, N., BALAMASH, K.S., ABULNAJA, K.O., YAGHMOOR, S.S., YOUSSRI, M.A., KUMOSANI, T.A. and MALKI, A.L.A., 2018. Multifaceted role of a marvel golden molecule, curcumin: a review. Indian Journal of Pharmaceutical Sciences, vol. 80, no. 3, pp. 400-411. http://dx.doi.org/10.4172/ pharmaceutical-sciences.1000372.

NIEDZWIECKI, A., ROOMI, M.W., KALINOVSKY, T. and RATH, M., 2016. Anticancer efficacy of polyphenols and their combinations. Nutrients, vol. 8, no. 9, pp. 552. http://dx.doi.org/10.3390/ nu8090552. PMid:27618095.

PETRELLI, N., DOUGLASS JUNIOR, H.O., HERRERA, L., RUSSELL, D., STABLEIN, D.M., BRUCKNER, H.W., MAYER, R.J., SCHINELLA, R., GREEN, M.D. and MUGGIA, F.M., 1989. The modulation of fluorouracil with leucovorin in metastatic colorectal carcinoma: a prospective randomized phase III trial. Journal of Clinical Oncology, vol. 7, no. 10, pp. 1419-1426. http://dx.doi.org/10.1200/ JCO.1989.7.10.1419. PMid:2674331.

RAJESH, E., SANKARI, L.S., MALATHI, L. and KRUPAA, J.R., 2015. Naturally occurring products in cancer therapy. Journal of Pharmacy E Bioallied Sciences, vol. 7, no. 5, suppl. 1, pp. S181-S183. http://dx.doi.org/10.4103/0975-7406.155895. PMid:26015704.
RAMOS, S., 2008. Cancer chemoprevention and chemotherapy: dietary polyphenols and signalling pathways. Molecular Nutrition \& Food Research, vol. 52, no. 5, pp. 507-526. http:// dx.doi.org/10.1002/mnfr.200700326. PMid:18435439.

ROOMI, M.W., JARIWALLA, N., ROOMI, N.W., RATH, M. and NIEDZWIECKI, A., 2011. A novel nutrient mixture exhibits antitumor activity in human fibrosarcoma cell line HT-1080. Cancer Research, vol. 71, no. 8, suppl., pp. 1500.

ROOMI, M.W., KALINOVSKY, T., ROOMI, N.W., NIEDZWIECKI, A. and RATH, M., 2015. In vitro and in vivo inhibition of human fanconi anemia head and neck squamous carcinoma by a phytonutrient combination. International Journal of Oncology, vol. 46, no. 5, pp. 2261-2266. http://dx.doi.org/10.3892/ijo.2015.2895. PMid:25695860.

SCALBERT, A., MANACH, C., MORAND, C., RÉMÉSY, C. and JIMÉNEZ, L., 2005. Dietary polyphenols and the prevention of diseases. Critical Reviews in Food Science and Nutrition, vol. 45, no. 4, pp. 287-306. http://dx.doi.org/10.1080/1040869059096. PMid: 16047496.

SIDDIQUI, A.A., IRAM, F., SIDDIQUI, S. and SAHU, K., 2014. Role of Natural Products in Drug Discovery Process. International Journal of Drug Development and Research, vol. 6, no. 2, pp. 172-204.

SIMONE II, C.B., SIMONE, N.L., SIMONE, V. and SIMONE, C.B., 2007. Antioxidants and other nutrients do not interfere with chemotherapy or radiation therapy and can increase kill and increase survival, part 2. Alternative Therapies in Health and Medicine, vol. 13, no. 2, pp. 40-47. PMid:17405678.

SOENGAS FERNÁNDEZ, M.P., SOTELO PÉREZ, T., VELASCO PAZOS, P. and CARTEA GONZÁLEZ, M.E., 2011 [viewed 14 February 2021]. Antioxidant properties of Brassica vegetables. Functional Plant Science E Biotechnology [online], vol. 5, no. 2, pp. 43-55. Available from: http://www.globalsciencebooks.info/Online/GSBOnline/ images/2011/FPSB_5(SI2)/FPSB_5(SI2)43-55o

SRIVASTAVA, S.K. and SINGH, S.V., 2004. Cell cycle arrest, apoptosis induction and inhibition of nuclear factor Kappa B activation in anti-proliferative activity of benzyl isothiocyanate against human pancreatic. Cancer Cells, vol. 25, no. 9, pp. 1701-1709. http://dx.doi.org/10.1093/carcin/bgh179. PMid:15117814.

ZHANG, G., ZHOU, X. and LIN, C., 2015. Efficacy of chemotherapy plus bevacizumab as first-line therapy in patients with metastatic colorectal cancer: a meta-analysis and up-date. International Journal of Clinical and Experimental Medicine, vol. 8, no. 1, pp. 1434-1445. PMid:25785152. 